\title{
Instrumen Pengukuran Kualitas Hidup Anak Terinfeksi HIV
}

\section{Quality of Life Measuring Instrument on Children HIV Infected}

\author{
Toha Muhaimin* Budi Utomo* Dharmayati B. Utoyo** Nia Kurniati*** Triyanti Anugrahini***** Fita R. Utami* \\ Enny Zuliatie ******
}

\begin{abstract}
*Fakultas Kesehatan Masyarakat Universitas Indonesia, **Fakultas Psikologi Universitas Indonesia, ***Fakultas Kedokteran Universitas
\end{abstract} Indonesia, ******Fakultas Ilmu Sosial dan Politik Universitas Indonesia, ******Yayasan Pelita Ilmu

\begin{abstract}
Abstrak
Anak penderita Human Immunodeficiency Virus/Acquired Immune Deficiency Syndrome (HIVIAIDS) di Indonesia memperlihatkan tren yang semakin meningkat karena meningkatnya proporsi perempuan terinfeksi HIVIAIDS. Pertimbangan pada dampak besar yang dihadapi anak penderita HIV mendorong kebutuhan pengembangan instrumen khusus untuk mengukur kualitas hidup mereka. Penelitian ini bertujuan mengembangkan instrumen kualitas hidup anak penderita AIDS dengan memodifikasi instrumen yang ada sesuai dengan konteks Indonesia. Pada penelitian ini ditemukan hasil bahwa instrumen yang dikembangkan mempunyai reliabilitas yang cukup baik pada balita dan anak usia $5-11$ tahun. Nilai reliabilitas (Cronbach's Alpha) balita, domain fungsi fisik, fungsi sosial, dan gejala HIV masing-masing adalah 0,$71 ; 0,72$; dan 0,88 , sedangkan pada anak 5 - 11 tahun, domain fungsi-fungsi fisik, psikologis, sosial, sekolah, dan gejala terkait HIV masing-masing 0,$76 ; 0,89 ; 0,67 ; 0,67$; dan 0,88 . Penelitian ini menunjukkan untuk konteks Indonesia, nilai ambang batas CD4 yang menunjukkan perbedaan kualitas hidup adalah 15\%. Pada balita, dari berbagai ketiga domain, hanya domain gejala terkait HIV yang cukup sensitif untuk mendeteksi perbedaan kualitas hidup anak, sementara pada anak 5 11 hanya domain fungsi fisik dan fungsi psikologis yang cukup sensitif untuk mendeteksi perbedaan kualitas hidup anak. Penelitian ini menunjukkan bahwa dampak HIV pada anak masih terkonsentrasi pada gangguan fungsi fisik, fungsi psikologis, dan gejala terkait HIV.
\end{abstract}

Kata kunci: Instrumen pengukuran, anak terinfeksi HIV, kualitas hidup

\section{Abstract}

Children with HIVIAIDS in Indonesia are increasing due to the increase of woman with HIV. A special instrument for measuring quality of life (QoL) of children with HIV is needed to be developed as the great impact of the infection to children. This study was conducted by modifying the existing QoL instrument of children for Indonesian context. The study indicated that the reliability of the instrument is quite good both for children under 5 and 5 -
11 years old. Reliability values (Cronbach's Alpha) for under 5, domains of physical function, social function, and HIV-related symptoms are 71,72 , and 88 respectively while for children $5-11$ years old, domains of physical, psychological, social, and school functions, and HIV-related symptoms are 76, $89,67,67$, and 88 respectively. The study showed, for Indonesian context, $15 \%$ of CD4 is indicated as the threshold to detect the difference of QoL for children with HIV. However, for under 5 years old, only questions of HIV-related symptoms domain which is sensitive to detect difference QoL, whereas for children of $5-11$ years old, the questions concerning physical and psychological domains which are sensitive to detect difference QoL. The study indicated that the impact of HIV on children is mostly on physical and psychological functions and HIV-related symptoms.

Key words: Measurement instrument, children with HIV, quality of life

\section{Pendahuluan}

Di Indonesia, jumlah kasus anak dengan Human Immunodeficiency Virus/Acquired Immune Deficiency Syndrome (HIV/AIDS) memperlihatkan kecenderungan yang semakin meningkat. Sampai dengan Maret 2010, jumlah kasus AIDS anak berusia di bawah 15 tahun dilaporkan mencapai 576 kasus, sedangkan untuk umur $15-19$ tahun mencapai 637 kasus. ${ }^{1}$ Hal tersebut diduga disebabkan oleh proporsi orang dengan HIV/AIDS (ODHA) perempuan, yang semakin meningkat, pada tahun 2007 (20\%), dan tahun 2009 (25\%). ${ }^{2}$ Layak diduga bahwa peningkatan proporsi AIDS pada perempuan tersebut akan meningkatkan frekuensi anak terinfeksi HIV. Diperkirakan sekitar 35\% anak akan terinfeks HIV dari

Alamat Korespondensi: Toha Muhaimin, Departemen Biostatistik dan Ilmu Kependudukan FKM Universitas Indonesia Gd. A Lt. 2 Kampus Baru UI Depok 16424,Hp.0811105266, e-mail: tohamuhaimin@yahoo.co.id 
ibu yang positif menderita HIV/AIDS. ${ }^{3}$ Selain itu, banyak anak-anak yang dilahirkan oleh ibu penderita HIV/AIDS tidak mendapatkan: pengobatan/perawatan yang mereka butuhkan, antiretroviral dan antibiotik, gizi yang cukup, air dan sanitasi yang bersih dan aman. Stigma dan diskriminasi pada ODHA juga memperburuk kondisi anak. ${ }^{3}$ Mereka juga bisa kehilangan kesempatan pendidikan karena keuangan keluarga yang memburuk dan biaya pendidikan yang tinggi. ${ }^{4}$ Anak-anak tersebut tentu saja akan mempunyai harapan hidup yang lebih pendek dan kualitas hidup (KH) yang rendah daripada anak-anak seusia mereka yang tidak menderita HIV/AIDS.

Beberapa penelitian menunjukkan, anak yang terinfeksi HIV akan mempunyai fungsi fisik dan psikososial yang lebih rendah daripada anak-anak yang tanpa HIV. ${ }^{5-}$ 7 Penelitian lain menunjukkan, anak yang terinfeksi HIV dengan tingkat imunitas lebih buruk, mempunyai kualitas hidup yang lebih rendah dibandingkan anak dengan imunitas lebih baik. 7-12 Pertimbangan tentang dampak besar yang dialami anak yang terinfeksi HIV, maka dipandang perlu untuk menilai besar dampak tersebut terhadap kualitas hidup anak tersebut. Hal ini dikarenakan kualitas hidup suatu kelompok termasuk anak yang terinfeksi HIV dikaitkan dengan indeks pembangunan manusia di suatu negara. ${ }^{13}$ Untuk itu diperlukan instrumen yang secara khusus dikembangkan untuk mengukur kualitas hidup anak yang terinfeksi HIV. Menurut Deyo dan Patrick dalam O'Connor, ${ }^{14}$ dengan mengembangkan instrumen spesifik maka beberapa domain yang khas dapat diidentifikasi.

Tujuan penelitian ini adalah mengembangkan sebuah instrumen pengukuran kualitas hidup anak terinfeksi HIV dengan memodifikasi instrumen yang ada. Modifikasi disesuaikan dengan kondisi Indonesia, yaitu beberapa dimensi khusus yang melekat pada anak terinfeksi HIV. Informasi yang dihasilkan instrumen khusus ini dapat dimanfaatkan untuk menunjang intervensi kesehatan dan sosial untuk melakukan upaya mitigasi pada anak terinfeksi HIV dan keluarganya.

\section{Metode}

Penelitian dengan desain potong lintang ini merupakan uji coba instrumen untuk mengukur kualitas hidup anak yang terinfeksi HIV. Domain kualitas hidup anak yang akan dikembangkan berdasarkan definisi WHO tentang sehat adalah keadaan lengkap fisik, mental, dan kesejahteraan sosial dan bukan hanya ketiadaan penyakit atau kelemahan. Tim peneliti menetapkan 4 domain kualitas hidup anak yang meliputi kesehatan fisik (fungsi fisik dan gejala fisik), kesehatan psikologis, kesehatan sosial, dan lingkungan (rumah dan sekolah). Keempat domain tersebut didefinisikan sebagai kemampuan anak dalam melakukan aktivitas dasar; gejala-gejala penyakit yang dialami anak; status psikologis positif dan negatif, termasuk suasana hati dan perasaan; kualitas hubungan interpersonal; dan kemampuan anak berinteraksi dengan kondisi lingkungan sosial atau sekolah. Masing-masing domain tersebut terdiri dari beberapa pertanyaan atau pernyataan yang merupakan hasil modifikasi beberapa instrumen pengukuran kualitas hidup anak, terutama anak terinfeksi HIV atau anak dengan penyakit kronis.

Instrumen tersebut antara lain meliputi General Health Assessment for Children (GHAC) yang dikembangkan oleh Pediatric AIDS Clinical Trials Group, dan Pediatrics Quality of Life (PedsQL). Pertanyaan pada instrumen GHAC dialihbahasakan ke bahasa Indonesia dan dengan perbaikan tampilan fisik untuk selanjutnya dilakukan adaptasi terhadap domain sosial dan sekolah oleh tim peneliti. Instrumen ini mempunyai pilihan jawaban dalam skala Likert. Beberapa pertanyaan hanya ditanyakan kepada anak umur 5-11 tahun mengingat pertimbangan perkembangan fisik, psikologis, dan sosial anak. Selain itu, ditambahkan pula beberapa pertanyaan data sosial demografi anak, pengasuh, dan anggota rumah tangga, serta data yang diperoleh dari rekam medis, yakni persen cluster of differentiation 4 (CD4) terhadap T Limfosit, Viral Load (VL), dan pengobatan antiretroviral (ARV).

Target populasi pada penelitian ini adalah pengasuh (bukan pembantu) anak yang terinfeksi HIV yang mendapatkan perawatan di Rumah Sakit (RS) Cipto Mangunkusumo, RSUD Tanggerang, RS Hasan Sadikin, juga yang didampingi oleh lembaga swadaya masyarakat (LSM). Kriteria inklusi untuk pengasuh adalah orang dewasa lebih dari 18 tahun, mengasuh anak terinfeksi HIV umur 6 bulan sampai 4 tahun atau $5-11$ tahun, telah mengasuh minimal 3 bulan terakhir serta berhak untuk memberikan informed consent. Kriteria eksklusinya adalah pengasuh yang mengasuh anak yang didiagnosis mengalami gangguan neurologis, perkembangan, ataupun psikiatri. Pengambilan sampel dilakukan dua tahap. Tahap pertama identifikasi anak terinfeksi HIV yang memenuhi syarat di klinik tempat berobat dan LSM pendamping di daerah penelitian, dan bersedia berpartisipasi dalam penelitian. Tahap kedua memilih pengasuh anak yang memenuhi kriteria inklusi dan eksklusi di klinik rumah sakit, pada kunjungan rumah, atau pun pada pertemuan di LSM, yang selanjutnya dilakukan wawancara.

Pengumpulan data di klinik/rumah sakit/LSM dilakukan di ruangan khusus yang disediakan pihak rumah sakit/klinik/LSM, sedangkan kunjungan rumah dilakukan di tempat responden merasa nyaman dan tanpa ada gangguan pihak ketiga. Pada penelitian ini, kerahasiaan sangat ditekankan agar responden merasa nyaman sehingga dapat memberikan jawaban yang sebenarnya 
dan menghindari dampak negatif yang tidak diinginkan pada responden. Sebelum dilakukan wawancara, petugas lapangan lebih dahulu membacakan inform consent yang berisi perkenalan diri, tujuan penelitian, manfaat penelitian, lama wawancara, penjaminan kerahasiaan, dan hak untuk menolak atau ikut serta dalam penelitian. Untuk manajemen data, pada kuesioner disediakan kolom kode jawaban yang dilengkapi oleh petugas lapangan. Kode tersebut dimasukkan ke dalam komputer dengan menggunakan perangkat lunak dengan mengaktifkan fungsi cek yang meliputi logika cek, rentang angka, dan lainnya. Untuk kerahasiaan, jawaban yang dimasukkan ke dalam komputer tidak mengikutsertakan nama.

Pada analisis data, variabel-variabel demografi serta data perkembangan anak disajikan dalam bentuk deskriptif baik proporsi maupun rata-rata. Variabel kualitas hidup merupakan variabel komposit yang didapatkan dengan cara memberi skor pada tiap pertanyaan atau pernyataan dari keempat domain, dan kemudian dijumlah, dan hasil penjumlahan skor ditransformasi ke dalam skala 0 - 100. Reliabilitas instrumen diketahui dengan melihat besarnya nilai Alfa Cronbach, sedangkan untuk mengetahui validitas konstruk akan dilakukan melalui hubungan antara kualitas hidup dengan beberapa parameter klinis, khususnya persen CD4.

\section{Hasil}

\section{Karakteristik Anak dan Pengasuh}

Rata-rata umur pengasuh/responden yang berjumlah 123 orang adalah 38 tahun dengan nilai median 34 tahun, kebanyakan pengasuh perempuan $(87,1 \%)$, hampir separuhnya merupakan tamatan SLTA (46\%), pengasuh yang tidak bekerja $(53,2 \%)$. Rata-rata umur anak adalah 5 tahun dengan perbandingan jenis kelamin yang seimbang meliputi perempuan (54\%) dan laki-laki (46\%).
Jumlah anak dengan status HIV yang sudah diketahui oleh anak tersebut hanya 6 orang $(4,8 \%)$. Persebaran pendidikan anak merata pada dua kategori sekolah dan tidak sekolah/belum sekolah masing-masing berjumlah $60(48,7 \%)$ dan $63(51,3 \%)$. Klasifikasi imunologi 86 anak yang terinfeksi HIV adalah 32 anak $(37,2 \%)$ tergolong normal (jumlah CD4 $\geq 25 \%$ ), sedangkan yang tergolong sedang (jumlah CD4 $=15 \%-24 \%$ ) dan berat (jumlah CD4 < 15\%) masing-masing adalah 34,9\% dan $27,9 \%$. Mayoritas anak yang terinfeksi HIV dirawat oleh orang tua kandungnya $(60,5 \%)$. Selain itu, yang membiayai kebutuhan ekonomi anak, seperti konsumsi dan pendidikan, kebanyakan adalah orang tua kandungnya $(59,7 \%)$. Orang tua kandung pula yang paling mengetahui kondisi anak tersebut secara fisik, sosial, dan psikologis anak $(61,3 \%)$ (Lihat Tabel 1).

\section{Kualitas Hidup Anak Terinfeksi HIV}

Nilai mean untuk masing-masing domain kualitas hidup anak kurang dari 5 tahun dan umur 5-11 tahun diperlihatkan pada Tabel 1 dan Tabel 2. Beberapa gangguan fungsi fisik yang sering terjadi pada anak antara lain gangguan sembuh dari sakit $(77,7 \%)$, gangguan nafsu makan $(72,6 \%)$, dan gangguan menyampaikan keinginan $(66,7 \%)$.

Sementara itu, gangguan psikologis pada anak yang paling sering dilaporkan antara lain anak merasa tidak ada yang menyayangi $(76,9 \%)$, anak kesulitan konsentrasi $(76,9 \%)$, anak terlalu menuntut perhatian $(75,4 \%)$, anak terlalu aktif $(70,8 \%)$. Dalam hal fungsi sosial, lebih dari separuh $(56,9 \%)$ anak mengalami hambatan dalam melakukan aktivitas sosial seperti bermain dengan teman sebayanya, beberapa perlakuan diskriminatif keluarga ataupun masyarakat, seperti ditolak menggunakan barang yang sama $(15,4 \%)$ dan bergunjing ten-

Tabel 1. Perawatan Anak oleh Anggota Rumah Tangga

\begin{tabular}{lccc}
\hline Anggota RT & $\begin{array}{c}\text { ART yang paling sering } \\
\text { merawat anak (\%) }\end{array}$ & $\begin{array}{c}\text { ART yang membiayai } \\
\text { kebutuhan ekonomi anak (\%) }\end{array}$ & $\begin{array}{c}\text { ART yang paling mengetahui } \\
\text { kondisi anak (\%) }\end{array}$ \\
\hline Orang tua kandung & 60,5 & 59,7 & 61,3 \\
Kakek/nenek & 27,4 & 26,6 & 25,8 \\
Paman/bibi & 4,8 & 9,7 & 4,8 \\
Saudara kandung & 0,8 & 0,0 & 0,8 \\
Pembantu & 0,0 & 0,0 & 0,8 \\
Lainnya & 6,5 & 4,0 & 6,5 \\
\hline
\end{tabular}

Tabel 2. Kualitas Hidup Anak Kurang 5 Tahun yang Terinfeksi HIV Menurut Domain

\begin{tabular}{lccccccc}
\hline Domain & Range nilai & Mean & Min. & Maks. & $\mathbf{2 5 \%}$ & $\mathbf{5 0 \%}$ & $\mathbf{7 5 \%}$ \\
\hline Fungsi fisik & $14-42$ & 34,24 & 22,00 & 41,00 & 32,00 & 35,00 & 37,25 \\
Fungsi sosial & $3-15$ & 14,59 & 10,00 & 15,00 & 15,00 & 15,00 & 15,00 \\
Gejala terkait HIV & $19-114$ & 98,17 & 64,00 & 114,00 & 92,25 & 101,00 & 107,00 \\
\hline
\end{tabular}


Tabel 3. Kualitas Hidup Anak Usia 5 - 11 Tahun yang Terinfeksi HIV Menurut Domain

\begin{tabular}{llllllll}
\hline Domain & Range Nilai & Mean & Min. & Maks. & $\mathbf{2 5 \%}$ & $\mathbf{5 0 \%}$ & $\mathbf{7 5 \%}$ \\
\hline Fungsi fisik & $22-78$ & 66,12 & 48,00 & 76,00 & 61,50 & 67,00 & 72,00 \\
Fungsi psikologis & $25-75$ & 58,78 & 38,00 & 75,00 & 53,00 & 61,00 & 65,50 \\
Fungsi sosial & $8-33$ & 30,92 & 20,00 & 33,00 & 29,50 & 32,00 & 33,00 \\
Fungsi sekolah & $5-25$ & 18,3 & 9,00 & 25,00 & 15,25 & 18,50 & 21,00 \\
Gejala terkait HIV & $19-114$ & 99,43 & 50,00 & 114,00 & 93,00 & 104,00 & 108,00 \\
\hline
\end{tabular}

Tabel 4. Statistik Deskriptif dan Estimasi Konsistensi Internal Reliabilitas Instrumen untuk Anak Umur Kurang dari 5 Tahun

\begin{tabular}{lccccccc}
\hline Domain & Jumlah Item & Range & Variance & Mean & Min. & Maks. & Alfa Cronbach \\
\hline Fungsi fisik & 14 & 0,91 & 0,08 & 2,45 & 2,07 & 2,98 & 0,71 \\
Fungsi sosial & 3 & 0,16 & 0,01 & 4,86 & 4,78 & 4,95 & 0,72 \\
Gejala terkait HIV & 19 & 1,26 & 0,17 & 1,83 & 1,19 & 2,45 & 0,88 \\
\hline
\end{tabular}

tang status HIV anak (15,4\%). Status HIV pada anak juga memberikan tambahan beban bagi sebagian besar anak $(81,5 \%)$ yang bersekolah. Tidak jarang anak tidak masuk sekolah karena harus berkunjung ke rumah sakit (76,7). Terkait dengan gejala HIV selama satu bulan terakhir, sebanyak 4 dari 5 anak mengalami 1 atau lebih gejala. Gejala yang paling sering dialami anak antara lain pilek atau sinus $(65 \%)$, batuk atau napas berbunyi $(61 \%)$, masalah kulit $(52,8 \%)$, dan hilangnya nafsu makan $(52,8 \%)$.

\section{Reliabilitas Instrumen}

Untuk menguji reliabilitas instrumen pada penelitian ini digunakan nilai Alfa Cronbach, yang merupakan nilai yang menjelaskan korelasi antarpertanyaan untuk menilai konsistensi internal dari masing-masing pertanyaan terhadap domain-domain kualitas hidup. Pada awal analisis reliabilitas diketahui bahwa beberapa pertanyaan atau pernyataan pada domain fungsi sosial harus dicabut agar menghasilkan nilai Alfa Cronbach minimal 0,70 yaitu nilai yang menunjukkan nilai konsistensi internal yang baik. Untuk fungsi sosial, pertanyaan yang cabut adalah "Secara umum, apakah anak mempunyai keterbatasan waktu bermain karena kondisi kesehatannya?"; "Secara umum, apakah anak terhambat melakukan permainan anak-anak karena kondisi kesehatannya?"; "Secara umum, apakah anak bisa melakukan permainan anakanak dengan teman sebayanya?"; "Selama satu tahun terakhir, pernahkah orang-orang bergunjing mengenai status HIV anak?" dan "Selama satu tahun terakhir pernahkah Anda mendengar kata-kata yang menyalahkan anak karena status HIV/AIDS?”. Pernyataan pada domain fungsi fisik yang mengalami pencabutan yaitu: "Tampak mudah marah" dan "Rentan mengalami cedera/luka (jatuh, tersandung, terbentur)”. Untuk domain gejala ter- kait HIV, tidak ada pertanyaan maupun pernyataan yang dihapus.

Hasil akhir yang ditunjukkan oleh Tabel 4 diketahui bahwa domain fungsi fisik, fungsi sosial dan gejala terkait HIV memiliki nilai Alfa Cronbach masing-masing $0,71,0,72$ dan 0,88 . Hasil ini menunjukkan bahwa instrumen ini cukup baik dalam menilai konsistensi internal untuk domain fungsi (Lihat Tabel 4). Umur 5-11 tahun ada penambahan domain fungsi psikologi dan fungsi sekolah. Pada kelompok umur ini juga dilakukan pencabutan beberapa pertanyaan dengan tujuan untuk meningkatkan nilai Alfa Cronbach menjadi minimal 0,70. Namun demikian, untuk fungsi sosial dan fungsi sekolah tidak bisa mencapai nilai 0,70 meskipun sudah dilakukan pencabutan beberapa pertanyaan. Ada 8 pertanyaan yang dihapus dalam domain fungsi sosial, sementara pada domain fungsi sekolah ada satu pertanyaan yang dihapus yakni "Lupa pelajaran yang diajarkan di sekolah". Domain fungsi fisik, fungsi psikologis, fungsi sosial, fungsi sekolah, dan gejala terkait HIV masing-masing nilai Alfa Cronbach-nya adalah 0,76; 0,89; 0,67; 0,67; dan 0,88 . Hasil ini menunjukkan bahwa instrumen ini cukup baik dalam menilai konsistensi internal, khususnya untuk domain fungsi fisik $(0,76)$, fungsi psikologis $(0,89)$, dan gejala terkait HIV $(0,88)$. Fungsi sosial dan fungsi sekolah, meskipun nilainya kurang dari 0,70 namun relatif dapat dikatakan baik karena hanya berbeda sedikit (3\%) dari batas nilai minimum (Lihat Tabel 5).

\section{Validitas Instrumen}

Untuk menilai validitas konstruk pada instrumen yang dikembangkan di sini, pada tahap awal dilakukan penghitungan rata-rata mean nilai kualitas hidup untuk mengetahui antara 3 klasifikasi imunologi (persen CD4) yang dikembangkan oleh WHO. Berdasarkan hasil 
Tabel 5. Statistik Deskriptif dan Estimasi Konsistensi Internal Reliabilitas Instrumen untuk Anak Umur 5 - 11 Tahun

\begin{tabular}{lccccccc}
\hline Domain & Jumlah Item & Range & Variance & Mean & Min. & Maks. & Alfa Cronbach \\
\hline Fungsi fisik & 22 & 2,66 & 0,93 & 3,01 & 2,03 & 4,69 & 0,76 \\
Fungsi psikologis & 25 & 0,85 & 0,06 & 2,35 & 1,91 & 2,75 & 0,89 \\
Fungsi sosial & 8 & 3,17 & 1,41 & 4,07 & 1,67 & 4,83 & 0,67 \\
Fungsi sekolah & 5 & 0,98 & 0,15 & 3,66 & 3,10 & 4,08 & 0,67 \\
Gejala terkait HIV & 19 & 1,11 & 0,13 & 5,23 & 4,63 & 5,74 & 0,88 \\
\hline
\end{tabular}

penghitungan terlihat bahwa pada konteks Indonesia, perbedaan nyata terlihat pada mean nilai kualitas hidup anak dengan klasifikasi persen CD4 normal (CD4 $\geq$ $25 \%)$ dan sedang $(\mathrm{CD} 4=15-24 \%)$ di satu kelompok, terhadap klasifikasi berat (CD4 < 15\%) di kelompok lain. Oleh karena itu, pada tahap selanjutnya dilakukan Uji T independen untuk melihat hubungan nilai kualitas hidup dengan dua kelompok klasifikasi imunologi, yakni kelompok persen CD4 normal hingga sedang terhadap kelompok berat. Pada kelompok anak umur kurang dari 5 tahun, hasil uji $\mathrm{T}$ independen menunjukkan bahwa hanya domain "gejala terkait HIV" kualitas hidup yang mempunyai korelasi dengan klasifikasi imunologi (nilai $p<0,05)$, sedangkan pada kelompok anak umur 5-11 tahun, hasil uji $\mathrm{T}$ independen menunjukkan bahwa domain kualitas hidup yang mempunyai korelasi dengan klasifikasi imunologi yakni fungsi fisik (nilai $p=0,05$ ) dan fungsi psikis (nilai $\mathrm{p}=0,02$ ).

\section{Pembahasan}

Untuk mencapai tujuan penelitian, mengembangkan instrumen pengukuran kualitas hidup anak terinfeksi HIV, dilakukan uji reliabilitas dengan melihat Alfa Cronbach, dan uji validitas dengan melakukan uji $\mathrm{T}$ independen. Pengukuran kualitas hidup anak terinfeksi HIV pada penelitian ini menunjukkan bahwa instrumen yang dikembangkan mempunyai reliabilitas internal yang cukup baik dan mampu membedakan antara anak dengan kondisi imunologi normal, sedang, dan berat. Nilai reliabilitas internal untuk anak umur kurang dari 5 tahun untuk domain fungsi fisik, fungsi sosial, dan gejala HIV masing-masing 0,$71 ; 0,72$; dan 0,88 , sedangkan untuk anak umur 5-11 tahun untuk domain fungsi fisik, fungsi psikologis, fungsi sosial, fungsi sekolah dan gejala terkait HIV masing-masing 0,$76 ; 0,89 ; 0,67 ; 0,67$; dan 0,88 .

Berdasarkan penelitian Oberdorfer et al, ${ }^{11}$ di Thailand yang juga mengadaptasi GHAC, menunjukkan tingginya konsistensi internal untuk domain fungsi fisik $(0,95)$, fungsi psikologis $(0,85)$, gejala terkait HIV $(0,92)$, dan juga untuk fungsi sosial $(0,71)$. Pada penelitian instrumen GHAC yang dilakukan pada penelitian AIDS Clinical Trial Group, ${ }^{9}$ juga menunjukkan tingginya konsistensi internal untuk domain fungsi fisik $(0,95)$, gejala terkait HIV $(0,89)$, fungsi psikologis $(0,90)$, dan juga fungsi sosial $(0,72)$. Jika membandingkan konsistensi internal kedua penelitian terdahulu dengan penelitian ini maka baik untuk anak umur kurang dari 5 tahun maupun 5-11 tahun, instrumen yang dikembangkan pada penelitian ini mempunyai konsistensi internal relatif lebih rendah, namun masih diatas batas standar, kecuali untuk domain fungsi sosial dan fungsi sekolah masih kurang sedikit.

Terkait dengan validitas instrumen, sesuai dengan asumsi bahwa rata-rata nilai kualitas hidup yang dijelaskan dalam domain-domain: fungsi fisik, gejala fisik, fungsi psikologis, fungsi sosial, dan lingkungan sekolah, dalam penelitian ini ditunjukkan nilai yang tinggi pada klasifikasi imunologi kelompok normal (CD4 $\geq 25 \%)$, menurun pada kelompok sedang $(\mathrm{CD} 4=15-24 \%)$, dan nilai terendah akan muncul pada kelompok berat (CD4 $<15 \%)$. Akan tetapi, hasil penelitian ini menunjukkan pada anak umur kurang dari 5 tahun, domain yang signifikan hanya fungsi gejala terkait HIV, dan pada umur 5 11 tahun domain yang signifikan adalah fungsi fisik dan fungsi psikologis. Hasil tersebut diperoleh setelah membagi klasifikasi imunologi ke dalam 2 kategori, yaitu CD4 $\geq 15 \%$ dan CD $4<15 \%$ karena perbedaan mean baru terlihat jelas pada dua kategori tersebut. Dengan demikian, dapat disimpulkan bahwa di Indonesia, nilai batas untuk klasifikasi imunologi berbeda dengan beberapa penelitian kulitas hidup anak terinfeksi lainnya yang membandingkan nilai kualitas kategori normal (CD4 $\geq$ $25 \%)$ dengan rendah $(\mathrm{CD} 4<25 \%)$, seperti hasil penelitian Oberdorfer et al, ${ }^{11}$ di Thailand yang juga menggunakan instrumen yang diadaptasi dari GHAC. Hasil yang sama juga ditemukan pada penelitian yang dilakukan Gortmaker et al. ${ }^{9}$

Hasil penelitian ini memperlihatkan bahwa tidak ada hubungan fungsi fisik dan fungsi sosial terhadap total kualitas hidup pada anak umur kurang dari 5 tahun yang terinfeksi HIV. Ini menunjukkan bahwa pertanyaanpertanyaan pada domain fisik dan sosial tidak cukup sensitif untuk mendeteksi fungsi fisik dan sosial pada anak umur kurang dari 5 tahun. Hal ini mungkin disebabkan pada kegiatan wawancara di lapangan menu- 
jukkan kesulitan orang tua untuk memahami kondisi anak yang masih kecil. Oleh karena itu, berdasarkan penelitian ini, penting dilakukan pengembangan lebih lanjut pertanyaan-pertanyaan untuk domain-domain pengukuran kualitas hidup anak HIV+ umur kurang dari 5 tahun.

Sementara itu, pada anak umur 5 - 11 tahun, fungsi sosial, fungsi sekolah dan gejala terkait HIV tidak menunjukkan hubungan signifikan terhadap kualitas hidupnya. Hal ini juga terkait dengan rendahnya Alfa Cronbach domain fungsi sosial dan sekolah, sedangkan untuk gejala terkait HIV, angka perbedaan mean antara kelompok imunologi cukup berbeda nyata namun tidak signifikan secara statistik. Hal ini menunjukkan bahwa pertanyaanpertanyaan pada domain fungsi sosial, sekolah, dan gejala terkait HIV tidak cukup sensitif untuk mendeteksi domain-domain tersebut. Untuk itu diperlukan pengembangan lebih lanjut pertanyaan-pertanyaan untuk domain-domain pengukuran kualitas hidup anak umur 5 -11 tahun.

Beberapa keterbatasan perlu dipertimbangkan saat melakukan interpretasi hasil temuan penelitian ini. Pertama karena penelitian ini merupakan studi potong lintang maka tidak bisa diketahui reliabilitas tes-retes. Kedua, kebutuhan waktu pengisian kuesioner yang ratarata menghabiskan 30 menit mungkin dirasakan kurang praktis untuk dilakukan pada studi-studi lainnya. Ketiga, sebanyak 26\% dari nilai persen CD4 dihasilkan dari tes yang dilakukan lebih dari 12 bulan yang lalu. Hal ini tentu saja mengakibatkan bias karena pada instrumen digambarkan kondisi anak selama 12 bulan sampai 1 bulan terakhir. Keempat, perlunya dilakukan identifikasi status terapi antiretroviral anak karena pada beberapa penelitian berpengaruh pada besarnya persen CD4 anak.

Penelitian lebih lanjut perlu dilakukan terutama yang bersifat evaluasi jangka panjang kualitas hidup anak, sehingga mampu mendeteksi perubahan kualitas hidup dengan perubahan persen CD4 sesuai dengan jangka waktu yang paralel. Selain itu perlu dikembangkan instrumen yang lebih ringkas berdasarkan hasil uji reliabilitas dan validitas penelitian ini. Namun, penelitian ini merupakan penelitian satu-satunya di Indonesia yang mengembangkan instrumen untuk mengukur kualitas hidup anak yang terinfeksi HIV. Dan hasil penelitian ini menunjukkan adanya peluang untuk mengimplementasikan instrumen ini untuk semua anak yang terinfeksi HIV di Indonesia. Penelitian ini juga menunjukkan bahwa dampak HIV pada anak masih terkonsentrasi pada gangguan fungsi fisik, psikologis, dan gejala terkait HIV. Oleh karena itu, informasi dari penelitian ini akan sangat berguna bagi petugas kesehatan dalam memberikan layanan yang lengkap dan sesuai dengan kebutuhan spesifik pada anak terinfeksi HIV.

\section{Kesimpulan}

Hasil penelitian ini menunjukkan bahwa instrumen yang dikembangkan mempunyai reliabilitas internal yang cukup baik, baik pada kelompok anak umur kurang dari 5 tahun maupun $5-11$ tahun. Nilai reliabilitas internal untuk anak umur kurang dari lima tahun untuk domain fungsi fisik, fungsi sosial, dan gejala HIV masing-masing 0,$71 ; 0,72$; dan 0,88 ; sedangkan untuk anak umur $5-11$ tahun, domain fungsi fisik, fungsi psikologis, fungsi sosial, fungsi sekolah dan gejala terkait HIV masing-masing 0,$76 ; 0,89 ; 0,67 ; 0,67$; dan 0,88 . Instrumen yang dikembangkan mampu membedakan nilai mean kualitas hidup anak dengan kondisi imunologi normal $(\mathrm{CD}=4 \geq 25 \%)$, sedang $(\mathrm{CD} 4=15 \%-24 \%)$, dan berat $(\mathrm{CD}=4<15 \%)$ secara deskriptif. Namun demikian, penelitian ini menunjukkan bahwa untuk konteks Indonesia, nilai ambang batas kondisi imunologi yang menunjukkan perbedaan kualitas hidup adalah $\mathrm{CD}=4<15 \%$ terhadap $\mathrm{CD}=5$ $\geq 15 \%$.

\section{Daftar Pustaka}

1. Kementerian Kesehatan Republik Indonesia, Direktorat Jenderal Pengendalian Penyakit dan Penyehatan Lingkungan. Laporan triwulan situasi perkembangan HIV dan AIDS di Indonesia sampai dengan maret 2010. Jakarta: Kementerian Kesehatan Republik Indonesia; 2010.

2. Kementerian Kesehatan Republik Indonesia, Ditjen Pengendalian Penyakit dan Penyehatan Lingkungan. Laporan triwulan situasi perkembangan HIV dan AIDS di Indonesia sampai dengan Desember 2007. Jakarta: Kementerian Kesehatan Republik Indonesia; 2007.

3. United Nations Children's Fund. Children affected by HIV/AIDS in South Asia: a synthesis of current global, regional, and national thinking and research. Nepal: United Nations Children's Fund; 2007 [diakses tanggal 19 Desember 2010]. Diunduh dari: http://www.unicef.org.

4. United Nations Educational, Scientific, and Culture Organization. HIV/AIDS and education. 2003 [diakses tanggal 19 Desember 2010. Diunduh dari: http://www.unesco.org.

5. Bomba M, Nacinovich R, Oggiano S, Cassani M, Baushi L, Bertulli C, et al. Poor health-related quality of life and abnormal psychosocial adjustment in Italian children with perinatal HIV infection receiving highly active antiretroviral treatment. AIDS Care. 2010; 22 (7); 858-65.

6. Byrne MW \& Honig J. Psychometrics of child health questionnaire parent short form (CHQ-28) used to measure quality of life in HIV-infected children on complex anti-retroviral therapy. Journal Quality of Life Researchi. 2005; 14: 1769-74.

7. Lee GM, Gortmaker SL, McIntosh K, Huges MD, Oleske JM. Quality of life of children and adolescent: impact of HIV infection and antiretroviral treatment. Pediatrics. 2006; 117: 273-83.

8. Diniz LO, Pinto JA. Quality of life of HIV-infected children in Brazil. Bol Med Hosp Infant Mex. 2009; 66: 325-34.

9. Gortmaker SL, Landerking WR, Clark C, Lee S, Fowler MG, Oleske JM, The ACTG 219 Team. Development and use of pediatric quality of life questionnaire in AIDS clinical trials: reliability and validity of the general health assessment for children. In Drotar D, ed. Measuring Health-Related Quality of Life in Children and Adolescents: Implication 
for Research and Practice. Mahwah NJ: Lawrence Erlbaum Associates; 2001. hal. 219-35.

10. Kuntawee C, Fungladda W, Kaewkungwal J, Chanthavanich P, Chotpittayasunon T. Social factors related quality of life among HIV-infected children in Ubon Ratchathani Province, Thailand. Southeast Asian Journal of Tropical Medicine and Public Health. 2010; 41 (5): 1136-44.

11. Oberdorfer P, Louthrenoo O, Puthanakit T, Sirisanthana V, Sirisanthana T. Quality of life among HIV-infected children in Thailand. Journal of the International Association of Physician in AIDS Care. 2008; xx (x): $1-7$.
12. Punpanich W, Hays RD, Detels R, Chokephaibulkit K, Chantibuddhiwet U, Leowsrisook P, Prasitsuebsai W. Development of culturally appropriate health-related quality of life measure for human immunodeficiency virus-infected children in Thailand. Journal of Pediatrics and Child Health. 2010; 47 (1-2): 27-33.

13. Muhaimin T. Mengukur kualitas hidup anak. Kesmas, Jurnal Kesehatan Masyarakat Nasional. 2010; 5 (2): 51-5.

14. O'Connor R. Issues in the measurement of health-related quality of life, NHMRC national centre for health program evaluation. Melbourne, Australia; 1993. 